\title{
Guidelines for Vector Surveillance and its Control at International Airports and Ports in India
}

\author{
SN Sharma', Ram Singh', Rina Kumawat ${ }^{3}$, Sujeet Kumar Singh ${ }^{4}$ \\ ${ }^{1,2,3,4}$ National Centre for Disease Control, Dte. General of Health Services, Ministry of Health \& FW, 22 - Sham Nath Marg, \\ Delhi, India. \\ DOI: https://doi.org/10.24321/0019.5138.202006
}

\section{I $\quad \mathbf{N} \quad \mathbf{F} \quad \mathbf{O}$}

\section{Corresponding Author:}

SN Sharma, National Centre for Disease Control, Dte. General of Health Services, Ministry of Health \& FW, 22 - Sham Nath Marg, Delhi, India. E-mail Id:

drsns.nvbdcp@gmail.com

Orcid Id:

https://orcid.org/0000-0001-8569-1661

How to cite this article:

Sharma SN, Singh R, Kumawat R, Singh SK. Guidelines for Vector Surveillance and its Control at International Airports and Ports in India. J Commun Dis 2020; 52(1): 38-60.

Date of Submission: 2020-03-11

Date of Acceptance: 2020-04-08

\section{$\begin{array}{llllllll}\mathbf{A} & \mathbf{B} & \mathbf{S} & \mathbf{T} & \mathbf{R} & \mathbf{A} & \mathbf{C} & \mathbf{T}\end{array}$}

\begin{abstract}
International Health Regulations (IHR) were brought into consideration during 1969 to which all the member states were required to notify to WHO any specific disease outbreaks/ public health emergencies of international concern within 24 hours through focal point, maintain sanitary standards at international borders and PoE as prescribed under IHR. In May 2005, the Fifty-eighth World Health Assembly adopted the new International Health Regulations (IHR, 2005), which came into force in July 2007. In the IHR, state parties are requested to designate airports, and ports that shall develop core capacities requirements, and where justified for public health reasons, may also designate ground crossing. To prevent the threat to Yellow Fever, Zika, Dengue/DHF, KFD, CCHF, Plaque etc., although efforts are being made to address the issue of prevention and control of vector borne diseases, yet lot is to be done in terms of infra-structure strengthening, capacity building, proper planning, implementation and strict monitoring and supervisions at all levels at the grassroot level. An attempt has been made in this regard to address the issue of vectors of Dengue/DHF, Zika, Yellow Fever and Rodents, flies and cockroaches. The guidelines regarding vector surveillance and control may be used as a basis for at PoEs i.e. International airports/ seaports. The development of a management plan for preparing and performing vector surveillance and applying public health measures within the framework of the 2005 IHR is the need of hour and should be a main focus. The primary aim of developing these guidelines is to assist public health authorities at PoE in strengthening core capacities and managing vector surveillance and control programmes by providing technical guidance and skills on the optimal use of resources, planning, monitoring, and decision-making.
\end{abstract}

Keywords: IHR, Vector, Surveillance

\section{Introduction}

Vector Borne Disease control across international borders is one of the important public health issues. India is having international ground crossings and bordering districts with Nepal, Bhutan, Myanmar, Bangladesh. The country is connected with air and water with other part of world with entry points at airports and seaports. Transmission dynamics across borders are generally similar to Indian climatic conditions. 
Vector-borne diseases (such as malaria, dengue, chikungunya, Zika virus, yellow fever) are reported in over 100 countries and put up to $60 \%$ of the world's population at risk of infection; more than 500 million cases are reported each year. ${ }^{1,2}$ International travel and transport play an important role in the rapid spread of vector-borne diseases all over the world-as borders become more porous and the speed and extent of travel and shipping increase, so too does the potential of the spread of reservoirs and pathogens relate to vector-borne diseases. There are presently 22 international airports and 12 seaports in the country, which act as point of entry and IHR regulations are to be strictly undertaken (Annexure: VII).

\section{International Health Regulations}

In the present context, Globalization and industrialization have opened and expanded trade and commerce, which in turn have provided impetus to increased air traffic. The rapid global growth of connectivity has been responsible for the spread of vectors and the disease ${ }^{3-5}$. To address the threat of global spread of vectors and vector-borne diseases, through Points of Entry (PoE), i.e. ports, airports between nations, WHO brought Member States under the umbrella of the International Health Regulations (IHR) in 1969 to which all the Member States were signatory. Member States were required to notify to WHO any specific disease outbreaks/ public health emergencies of international concern within 24 hours through focal point, maintain sanitary standards at international borders and PoE as prescribed under IHR. In May 2005, the Fifty-eighth World Health Assembly adopted the new International Health Regulations, which came into force in July $2007 . .^{6-8}$ In the IHR, State Parties are requested to designate airports, and ports that shall develop core capacities requirements and where justified for public health reasons, may also designate ground crossing. One of the underlined areas is capacity building for vector surveillance and control at PoE.

The countries shall establish programmes to control vectors that may transport infectious agents constituting a public health risk. Such programmes must ensure that vectors are controlled to a minimum distance of 400 metres from those areas of point-of-entry facilities that are used for operations involving travellers, conveyances, containers, cargo, and postal parcels, with extension of the minimum distance if vectors with a greater range are present. The IHR (2005) also stipulates that competent authorities are required to ensure that facilities used at PoE are maintained in a sanitary condition and are kept free of sources of infection and contamination, including vectors and reservoirs; conveyance operators are so tasked for conveyances. ${ }^{9-10}$

\section{Purpose and Scope}

Due to the new challenges/ requirements brought about by the 2005 IHR, necessary efforts are being made in India to ensure effective vector surveillance and control at PoE. The present guidelines are aimed at assisting States to comply with the obligations of the IHR by providing technical advice for developing a comprehensive programme for systematic monitoring of vectors and an integrated vectorcontrol plan at points of entry. It is also intended for use by port health officers, airport health officers, border health officers, regulators, port operators, and other competent authorities in charge of implementing the 2005 IHR at points of entry. The guidelines regarding vector surveillance and control may be used as a basis for the development of a management plan for preparing and performing vector surveillance and applying public health measures within the framework of the 2005 IHR. The primary aim of developing these guidelines is to assist public health authorities at PoE in strengthening core capacities and managing vector surveillance and control programmes by providing technical guidance on the optimal use of resources, planning, monitoring, and decision-making. ${ }^{3}$

The following is an overview of various steps recommended for implementing the 2005 IHR provisions for vector control at points of entry (Figure 1 ). ${ }^{3}$

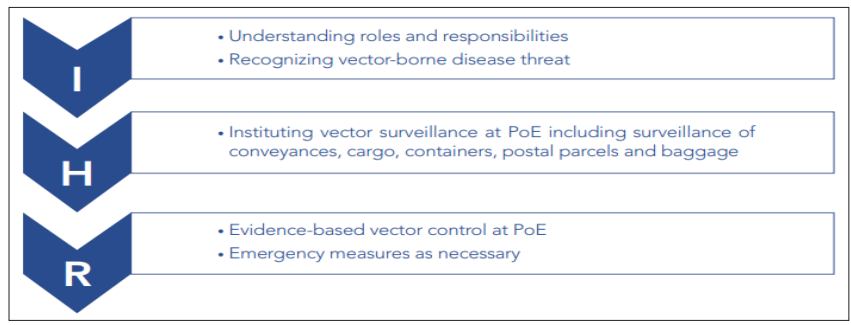

Figure I.Steps Recommended for Implementing the 2005 IHR Provisions for Vector Control

\section{Roles and Responsibilities}

APHO should, subject to International Health Regulations, establish and revise national or local relevant laws and regulations and ensure their effective implementation. A national or State level inter-sectoral cooperation mechanism may be established especially for the implementation of integrated vector management (Annexure I to IV). The concern authorities are responsible for the supervision of vector surveillance and control within the scope set out in this guidance, as well as for transferring technical knowhow and operational vector-control skills to operators to carry out vectors control.

The PoE authorities should conduct surveillance and apply public health measures with an aim to keeping vectors density below the threshold level set by national policies and practices. Technical cooperation for vector surveillance and control should be strengthened between stakeholders or other public organizations. This includes establishing and updating relevant technical regulations, information 
communication, personnel training, and technical support. PoE should identify partner institutions/laboratories which will assist in identification of vectors, reservoirs of infections and pathogens.

\section{Arthropods of Public Health Importance}

Ae. aegypti is the main vector in most urban areas (Figure 2); however, Ae albopictus is also found as vector in few areas of southern and eastern India.

The Ae. aegypti mosquito lives in urban habitats and breeds mostly in man-made containers. Unlike other mosquitoes

\begin{tabular}{|c|c|c|}
\hline Arthropod & Disease & Agent \\
\hline \multicolumn{3}{|l|}{ Mosquitoes } \\
\hline \multirow[t]{2}{*}{ Anopheles spp. } & Malaria & Plasmodium spp. \\
\hline & Lymphatic Filariasis & Brugia timori \\
\hline \multirow[t]{2}{*}{ Culex spp. } & Lymphatic Filariasis & Wuchereria bancrofti \\
\hline & West Nile & West Nile virus \\
\hline Culex Vishnui group & Japanese encephalitis & Flavivirus \\
\hline \multirow[t]{2}{*}{ Mansonioides spp. } & Lymphatic Filariasis & Brugia malayi \\
\hline & Lymphatic Filariasis & Wuchereria bancrofti \\
\hline \multirow[t]{4}{*}{ Aedes spp. } & Dengue / DHF / DSS & Dengue Virus Serotypes I., II, III \& IV \\
\hline & Chikungunya & Chikungunya virus \\
\hline & Zika & Zika Virus \\
\hline & Yellow Fever & Yellow Fever Virus \\
\hline \multirow[t]{2}{*}{ Phlebotomous spp. } & Visceral Leishmaniasis & Leishmania donovani \\
\hline & Cutaneous Leishmaniasis (Oriental Sore) & Leishmania tropica \\
\hline \multirow[t]{3}{*}{ Fleas } & Bubonic Plague & Yersinia pestis \\
\hline & Murine Typhus & Rickettsia typhi \\
\hline & Tungiasis & Tunga penetrans \\
\hline \multirow[t]{4}{*}{ Housefly } & Q Fever & Coxiella burneti \\
\hline & Amoebic Dysentery & Entamoeba, Giardia \\
\hline & Bacillary Dysentery & Shigella \\
\hline & Cholera & Vibrio cholera \\
\hline \multicolumn{3}{|l|}{ Hard Tick } \\
\hline Haemophysalis spinigera & Kyasanur Forest Disease (KFD) & Flavivirus \\
\hline Dermacentormarginatus & Tick Paralysis & Rickettsia \\
\hline Dermacentormarginatus & Tick borne encephalitis & Virus \\
\hline $\begin{array}{c}\text { Soft Tick } \\
\text { Ornithodorosspp }\end{array}$ & Endemic Relapsing Fever & Borrelia duttoni \\
\hline $\begin{array}{c}\text { Mites } \\
\text { Trombiculid Mite }\end{array}$ & Scrub Typhus & Rickettsia \\
\hline
\end{tabular}

\section{Dengue}

Dengue is a mosquito-borne viral infection. The infection causes flu-like illness, and occasionally develops into a potentially lethal complication called Dengue Haemorrhagic Fever (DHF) and Dengue Shock Syndrome (DSS). In India, it is a daytime feeder; its peak biting periods are in the morning and in the evening before dusk.

Diagnosis of the dengue virus is done by using NS1 or Elisa IgM Tests. There is no specific treatment for dengue fever. Antipyretics and cold sponging may be used to lower the body temperature. 


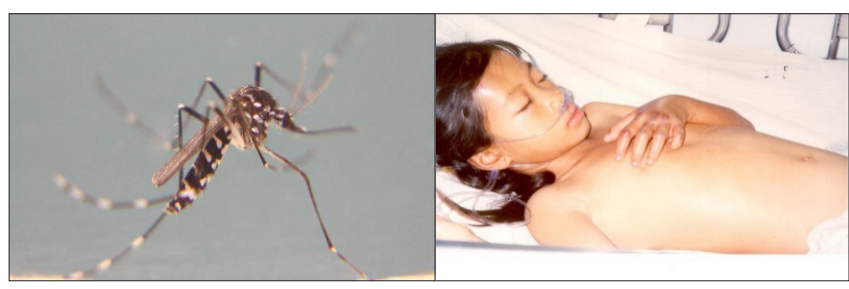

Figure 2.Dengue Vector and Patient

\section{Chikungunya}

Chikungunya is a viral disease transmitted to humans by infected Aedes mosquitoes. It causes fever and severe joint pain. Other symptoms include muscle pain, headache, nausea, fatigue and rash.

Chikungunya is characterized by an abrupt onset of fever frequently accompanied by joint pain. Other common signs and symptoms include muscle pain, headache, nausea, fatigue and rash. The disease shares some clinical signs with dengue, and can be misdiagnosed in areas where dengue is common. There is no cure for the disease. Treatment is focused on relieving the symptoms.

The virus is transmitted from human to human by the bites of infected female mosquitoes. Most commonly, the mosquitoes involved are Aedes aegyptiand Aedes albopictus, two species which can also transmit other mosquito-borne viruses, including dengue. These mosquitoes can be found biting throughout daylight hours, though there may be peaks of activity in the early morning and late afternoon. Both species are found biting outdoors, but Ae. aegypti will also readily feed indoors.

\section{Breeding Habitats}

Ae. aegypti is more closely associated with human habitation and uses indoor breeding sites, including flower vases, water storage vessels and concrete water tanks in bathrooms, as well as the same artificial outdoor habitats as Ae. albopictus (Figure 3).
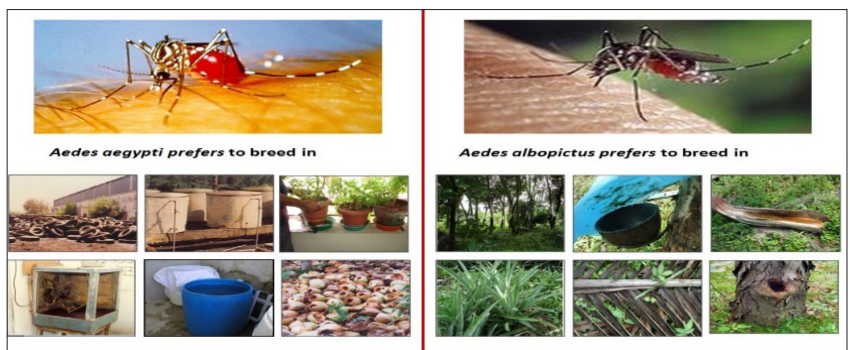

Figure 3.Breeding Sites of Ae. aegypti and Ae. albopictus

\section{Life Cycle}

The life cycle of mosquito vector has four distinct stages: egg, larva, pupa and adult (Figure 4). The time taken for the various stages to develop depends upon the temperature and nutritional factors.

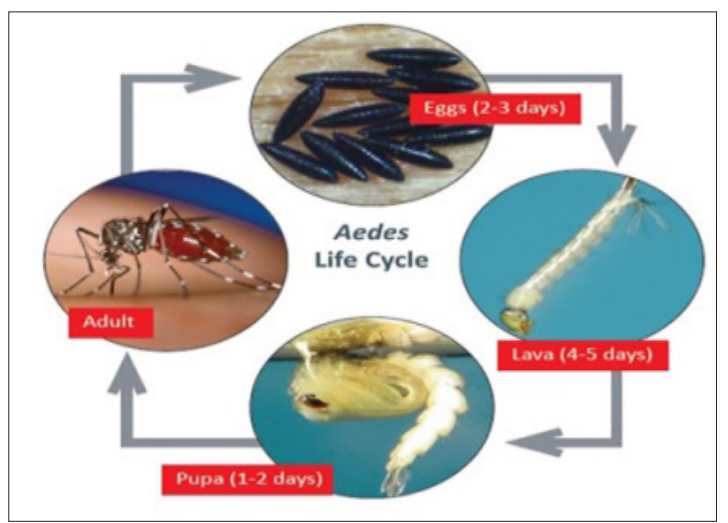

Figure 4.Life Cycle of Dengue Vector

\section{Eggs}

A female mosquito normally mates only once in the life time and usually requires a blood-meal after mating before the eggs can develop. Blood meals are generally taken every 2-3 days, before the next batch of eggs is laid. About 100-150 eggs are laid single on the water surface during oviposition. Multiple Oviposition sites can be seen varying from small containers to big in the preferred shady places and indoor situations mostly (Figure 5).

Under the most favourable conditions in the tropics, the average life span of an adult mosquito is 3-4 weeks. A female mosquito continues to lay eggs through its life and most will lay 1-3 batches of eggs, though some may lay as many as 7 batches.

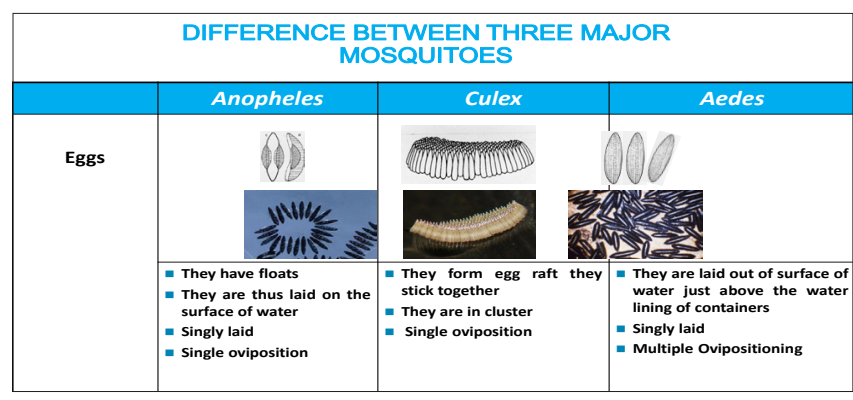

Figure 5.Identification of Eggs

\section{Larva}

A larva hatched from the eggs after 1-2 days and generally floats below and hangs to the water surface, where its breaths air (Figure 6). It feeds by filtering food particles from the water. When it gets disturbed the larva swims quickly downwards, but soon come to the water surface to breathe. There are four larval stages knows as instars. The small larvae emerging from the egg is called the forts instar. After 1-2 days, it sheds its skin and becomes the second instar, followed by the third and fourth instar at further intervals of about two days. The larva remains in the fourth stage for 3-4 days before changing into pupa. The total time spent in the larval stage is generally 8-10 days at 
normal tropical water temperature. At lower temperatures, the aquatic stages take longer time to develop. Depending upon the species, larvae may be found in small containers, coolers, overhead tanks, artificial fountains, thrown away utensils, cement tanks, tyres, unused wells.

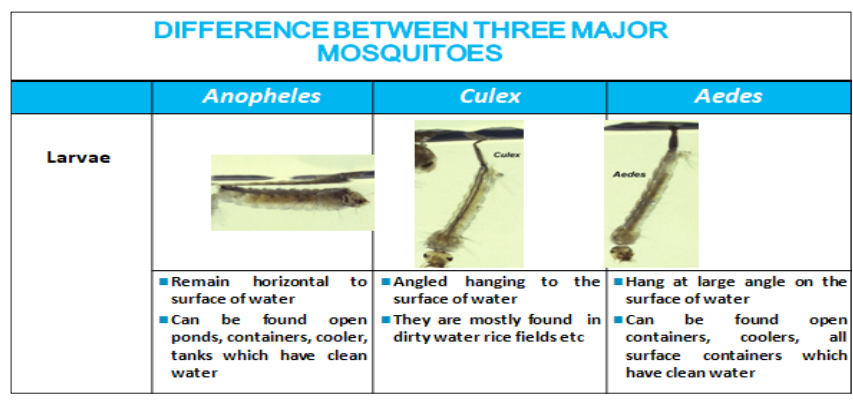

Figure 6.Identifying Aedes larval form

\section{Pupa}

The pupa undergoes a major transformation from living in water to becoming a flying insect as adult mosquito. The pupa is shaped like comma. It stays under the surface and swims down when disturbed. The pupae do not feed and is a non-feeding stage. The pupal stage lasts for 2-3 days after which the skin splits. The adult mosquito then emerges and rests temporarily on the water surface until it flies.

\section{Adult}

Mating takes place soon after the adult emerges from the pupa. The adult sits in hunch back and is ornamental with stripes and spots, hence names as tiger mosquito (Figure 7). The female usually mates only once because sufficient sperms are received from a single mating for all subsequent egg batches. Normally, the female takes the first bloodmeal only after mating, but sometimes the first blood meal is taken by young virgin females. The first batch of eggs develops after one or two blood meals (depending on the species), while successive batches usually require only one blood meal. The feedings and resting habits of mosquitoes are of great importance for vector control point of view. Aedes mosquitoes rest indoor, feed indoors and is diurnal in nature. Aedes mosquitoes is highly anthropophilic in nature.

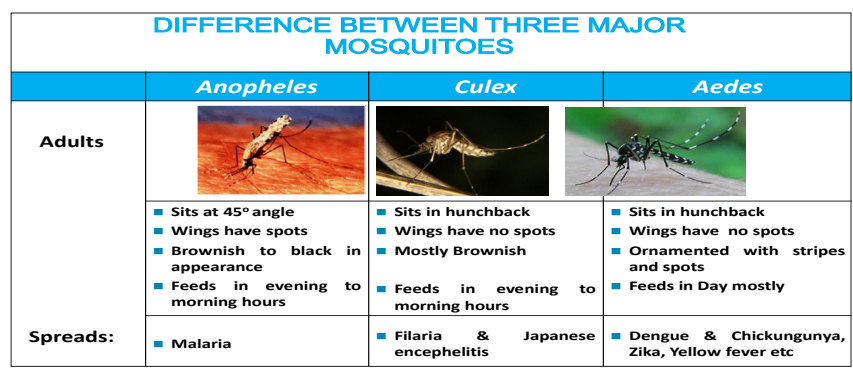

Figure 7. Identification of Aedes - Adult Mosquito Threshold Levels of Native and Invasive Species

The threshold for initiating control action against any invasive species at PoE should be zero. Mosquitoes are a case in point: even if the number of larvae/ dip or adults captured during landing or trap collection are few, fullscale surveillance would be warranted to know the extent of the invasion at PoE - with the aim of eliminating the invasive species with all available resources. Mosquito species-specific threshold levels Mosquito species differ in their choices of breeding habitats, flight ranges, feeding behaviour, and activity rhythms.

Ovitraps in the form of $500 \mathrm{~mL}$ containers, which are painted black on the outside and filled with water (3/4 capacity), can be placed randomly in an area where surveillance is intended for the presence of adult aedes mosquitoes. Experience has shown that a flat $2 \times 4$ inch cardboard strip immersed in the ovitraps water and hay infusion will enhance attractiveness of the trap. These traps are useful for determination of vector populations and assessment of impact of interventions in a given area. It is suggested placing $10 \%$ more ovitraps than calculated as needed, to allow for loss of traps due to natural disturbance or unintentional removal.

\section{Larval Counts}

Mosquito larvae go through four developmental stages called instars, usually referred to as 1st to 4th instar larvae, which eventually turn into pupae. In the case of Aedes breeding, if the combined larval and pupal count exceed on average $>5 /$ dip (also taking zeros into account) and if $>25 \%$ of all samples are positive for immature mosquitoes, it should mark the threshold for control action. ${ }^{4}$

However, when located near human inhabitation, larval counts of $>2$ larvae/dip in manmade containers or natural habitats might warrant control. For Aedes species, a House Index of $>5 \%$ and Breteau Index of $>20 \%$ should sound an alarm and would warrant immediate control action at PoE. The detection of invasive Aedes species should sound the alarm and would warrant immediate control action at PoE.

\section{Early Warning Signals}

- Breteau index more than 50: high risk of transmission

- Breteau index less than 5: low risk of transmission

- House index more than 10 percent: high risk of transmission

- House index less than 1 percent: low risk of transmission

- Biting rate more than 2 per man hour: high risk of transmission

- Biting rate less than 0.2 per man hour: high risk of transmission

\section{Adult Mosquito Threshold}

Various threshold levels have been suggested for native mosquitoes based on different levels of incidence and types of traps. Ovitraps are particularly useful in monitoring 
Aedes activity in an area and can help determine population levels in space and time.

\section{Developing Surveillance and Vector Control Plans}

The following components may be included in the surveillance and vector control plans:

- Situation analysis

- Identify risk factors

- Local entomological situation;

- Infra-structure assessment (requirement / available)

- Training (skill competency)

- Budgetary requirements

- Requirements of insecticides / larvicides / equipment's

- Reconnaissance of the PoE area and surrounding 400-metre perimeter or wider

- Mapping of breeding potential sites

- Vector surveillance

- Vector management

- Monitoring \& supervision

\section{Implementation of Surveillance Plan}

The airport/ port area may be divided into small sectors based on building or non-building area (Field). Fortnightly visits may be planned to search all the sectors as per the beat programme to be covered on assigned days by the respective teams. Field operation shall focus on the presence and identification of target vector in a particular habitat. Field samples may be collected from field samples and transported to the laboratory for further processing. A plan for comprehensive dengue - vector control strategy can be made and depicted below (The approved insecticides and larvicides are listed and shown in annexure: $\mathrm{VI}$ ) keeping in view its life cycle (aquatic and adult stages).

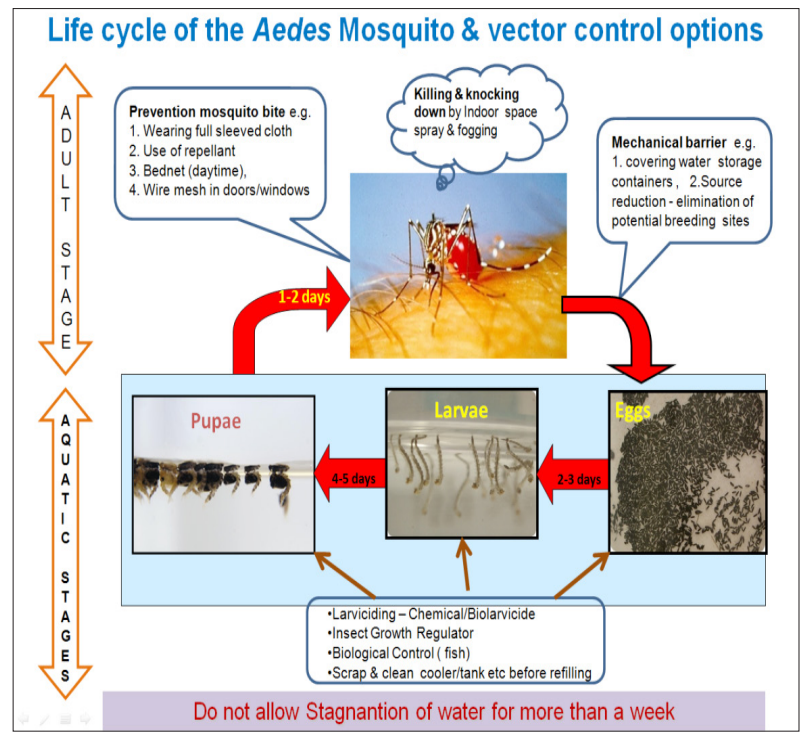

Figure 8. Plan for Comprehensive Dengue - Vector Control Strategy

\section{House Fly}

The housefly is known in all areas of the world and is the most widely distributed insect of importance to humans. In general, the housefly is gray in color and the thorax has four broad, dark stripes running longitudinally. The mouthparts are the sponging type and are adapted for taking up Liquefied food (Figure 8). They are most abundant in warm, humid climates. Houseflies, which comprise the majority of all flies, found in homes and food service facilities are the most important of the nonbiting species in the transmission of diseases. These flies spread disease "mechanically;" that is; they land on a contaminated site (that is, pathogencontaining faeces), get pathogens stuck to various body parts, and then contaminate our food when they land on it to feed. The medical history of past wars indicates that the health of troops has been seriously affected by flies. They carry the organisms that cause dysentery and may carry those which cause cholera, typhoid, and other diseases. In the tropics, various skin and eye diseases may be spread by flies. These include such serious diseases as yaws and trachoma.

\section{Life Cycle}

All flies have complete metamorphosis with four distinct stages in their life cycle: eggs, larvae, pupae, and adults (Figure 9).

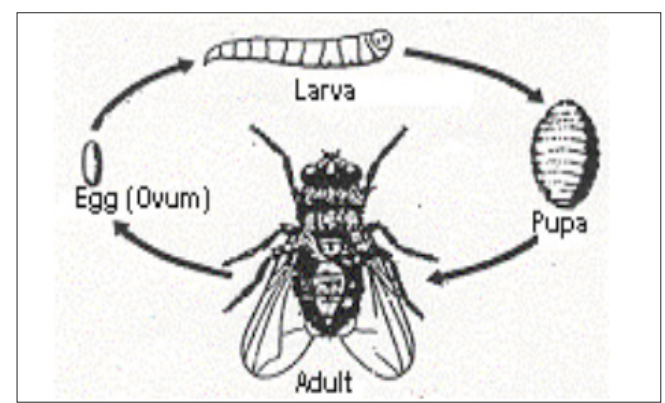

Figure 9. Life Cycle of Housefly (Musca domestica)

The adult female lays her eggs in garbage, pit latrines, animal manure, spilled animal feed and soil contaminated with organic matter. Houseflies are very prolific; the female lays several masses of eggs. The eggs hatch in less than 24 hours under ideal environmental conditions. The maggots are white and about one-half inch long when mature. This is the larval stage, which lasts from 3 to 24 days depending on temperature. In warm weather, this stage develops rapidly in 3 to 7 days. When the full-grown larvae are ready to pupate, they move out of the breeding site into dry soil. The pupal stage lasts from 3 to 5 days, depending upon the temperature. When the pupal stage is completed, the adult emerges from the pupal case, works its way to the surface of the ground and after its exoskeleton dries and hardens, flies away to feed. Mating may take place a day or two following emergences from the pupal case. 


\section{Fly Control Measures}

\section{Environmental Sanitation and Hygiene}

- Undertake short term and long term control of flies in urban areas, villages, individual farms and hospitality industry by practices of sanitation and hygiene.

- Prevent ingress of flies from other areas by eliminating sources of attraction.

\section{Elimination or Reduction of Fly reeding}

- Remove regularly the animal dung and manure.

- Lay concrete flooring with proper drainage. Poultry houses.

- $\quad$ Remove droppings under the cages or net bottoms.

- Treat with systemic larvicides such as Larvadex containing Cyromazine through feed.

- Remove the dung heaps regularly.

- Cover the heaps with plastic sheets to prevent the flies from laying eggs.

- The plastic sheet covering raise the temperature above $50 \mathrm{C}$ which kills the fly larvae. Human excrement.

- Adopt proper disposal of human excrement through (i) providing proper latrines, (ii) educate public to bring change of habits.

- Remove the exposed faeces regularly.

- Instal functional aqua privies with a vent pipe and fly net to make them fly-proof.

- Cover the lids of pits to make them fly proof Garbage disposal, collection and transport.

- Providing fly proof garbage containers of sufficient capacity.

- Transport the garbage at pre-determined intervals to the final disposal site.

- Avoid spillage of garbage during its transportation.

\section{Sewage and Waste Water Management}

- Cover all sewage drains.

- Cover sewage sludge with dry soil.

\section{Community Education and Participation}

- Educate the community in co-ordination with municipal authorities for collection, transportation and disposal of waste.

- Educate the community to keep the neighbourhood clean through - (a) education of children in school, (b) dessimation of information to general public through demonstrations, television channels and newspaper and (c) involvement of key stakeholders- local politicians, legislators and administrators etc. e.g. Non-Chemical methods of fly control.

- Adopt physical killing methods like catching of flies in traps or using electric grids having sticky pads.

- $\quad$ Fix screens to windows and doors with 10-gauge mesh to prevent entry of flies.

- Fix doors of auto closing.

- Fix anti-fly or air curtains in production facilities to keep away flies.

\section{Chemical Control Methods}

Larviciding (maggot control) Elimination of fly breeding at source naturally eliminates maggots also. However, maggot control is beset with many problems. The breeding media (manure) not only keeps on accumulating and changing but also distribution of larvicide and its penetration in viscous media becomes difficult leading to poor control. Also use of conventional larvicides result in killing of natural enemies of flies thus disrupting biological balance

Insect growth regulators Diflubenzuron and Pyriproxyfen are promising alternatives to conventional larvicides that can be used for control of fly larvae (Table 1). These larvicides do not have effect on many nontarget fauna in the manure and are eco-friendly with relatively very high safety margin to vertebrates.

Residual spraying of target sites:

- Identifying areas where flies spend most of their time.

- $\quad$ Spot spraying with adulticides on surfaces where flies rest during day time and night time.

- Carry residual spraying is carried out by knapsack or compression sprayer with flat fan nozzle with the chemicals listed below.

- Use these insecticides on surfaces (on need base) wherever flies congregate in indoor or outdoor situations including refuse dumps, recreational areas, markets etc.

- Take adequate care that the food items or utensils are not contaminated.

\section{Table I.Larvicides for Fly Control}

\begin{tabular}{|c|c|c|c|c|}
\hline Product & Dilution & Application & Frequency & Target sites \\
\hline $\begin{array}{c}\text { Diflubenzuron } \\
25 \text { WP }\end{array}$ & $\begin{array}{c}\text { Mix 15 mg } \begin{array}{c}\text { in litres of } \\
\text { water }\end{array} \\
\text { Pyriproxyfen } \\
0.5 \% \text { GR }\end{array}$ & $\begin{array}{c}\text { Spray over 10 square meters with } \\
\text { compression sprayer having flat fan } \\
\text { nozzle }\end{array}$ & 7-13 days & $\begin{array}{c}\text { Breeding sites in poultry, } \\
\text { animal shed, sewage sludge } \\
\text { etc. }\end{array}$ \\
\hline & $\begin{array}{c}20 \mathrm{~g} / \text { Square meter } 10 \mathrm{~g} / \text { square meter } \\
\text { By hand granule applicator, blower } \\
\text { with granule nozzle }\end{array}$ & $\begin{array}{c}2 \text { weeks } \\
\text { interval }\end{array}$ & $\begin{array}{c}\text { livestock and poultry houses or } \\
\text { waste treatment facilities }\end{array}$ \\
\hline
\end{tabular}




\section{Cockroach}

According to the World Health Organization (WHO), Cockroaches are proven or suspected carriers of the organisms causing diarrhoea, dysentery, cholera, leprosy, plague, typhoid fever and viral diseases such as poliomyelitis. They can spread disease, contaminate the food and cause allergies and even asthma. Cockroaches can pick up disease pathogens on their legs and bodies as they crawl through decaying matter or sewage and then transfer these germs to food or onto food surfaces.

The equipment required to conduct a professional cockroach inspection including heavy duty flash light, a mechanic mirror a flushing agent and a screwdriver. Hand Magnifying lens, plastic vials (Figure 10).

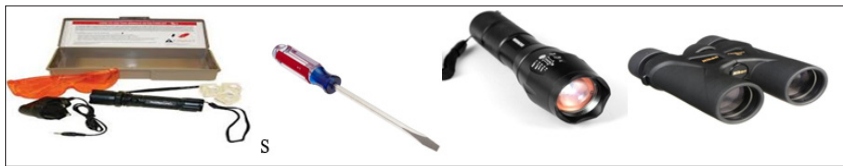

Figure 10. Surveillance Tools

The procedural steps include locating the cockroach habitats, mapping their distribution in the premises/ locality, initiating both chemical and non-chemical methods. A typical search should begin in the kitchen, bathroom, water sinks, storage areas, dining areas, behind and under food processing equipment, and loading and unloading areas.

\section{Mapping of Infestation Spots}

After locating the cockroach habitations, mapping needs to be done on the indoor and outdoor areas. The map should include spots of all cockroach sightings, area where frass is spotted, conditions which are conducive to cockroach presence, level of sanitation, location of sensitive areas and other treatment considerations. This leads to customization of various insecticide application and other management efforts ensuring successful result with non-target species safety and minimum number of treatments.

\section{Diagnose species of public health importance}

Although four species of cockroaches occur in India, German cockroach (Blatella germanica) and American cockroach (Periplanata americana) are of common occurrence in India (Figure 11).

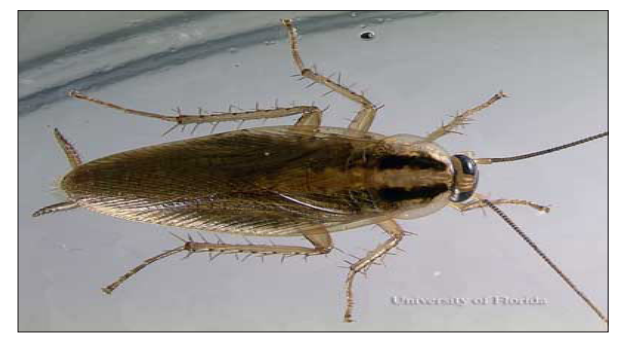

Figure I I.German Cockroach

\section{German Cockroach (Blatella germanica)}

The characteristic features:

- $\quad$ Lives in cracks, crevices and dark spots in the building provided by furniture, wall cabinets and numerous household items, which provide the optimal conditions for growth and development.

- They are brown to dark in color, $1.1-1.6 \mathrm{~cm}$ long with two block stripes behind the head and nymphs resembling the Adults

- The females produce 4 to 8 egg capsules in its life time, each capsule (ootheca). The capsule is a tiny, brown, purse-shaped capsule. Containing 30 - 40 eggs.

- Nymphs do not possess wings and complete development takes about 60 days.

\section{American Cockroach (Periplanata americana)}

The characteristic features:

- American cockroaches normally live outdoors and are common in sewer systems (Figure 12).

- They live in warm and humid environment and common in store rooms, cabinets, manholes, drains and all dark places in the premises.

- On entry inside homes, they often go to bathrooms, kitchens, laundry rooms and basements.

- American cockroaches provide signs of their presence through their droppings in the dark areas where they hide and often confused for mouse droppings.

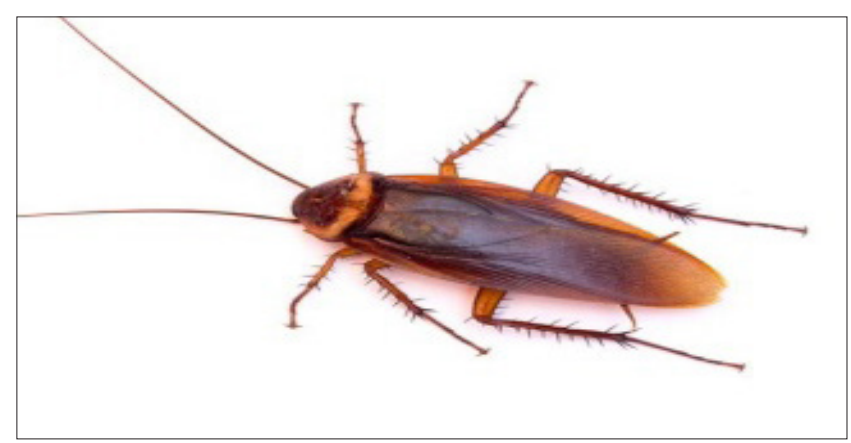

Figure I2. American Cockroach

- The egg cases can be found in basements, in laundry rooms or kitchens, under cabinets or behind appliances.

- They are reddish brown in color and varies from 34 to $50 \mathrm{~mm}$ in length.

- The area behind their head is outlines with yellow band.

- The females make protective cases - capsules containing about 16 eggs, and deposits them in a warm, humid area.

- On hatching tiny nymphs emerge, which are reddish brown in color resembling adults and mould $6-14$ times in 6 - 20 months to mature. The adults live up to 22 months (Figure 13). 


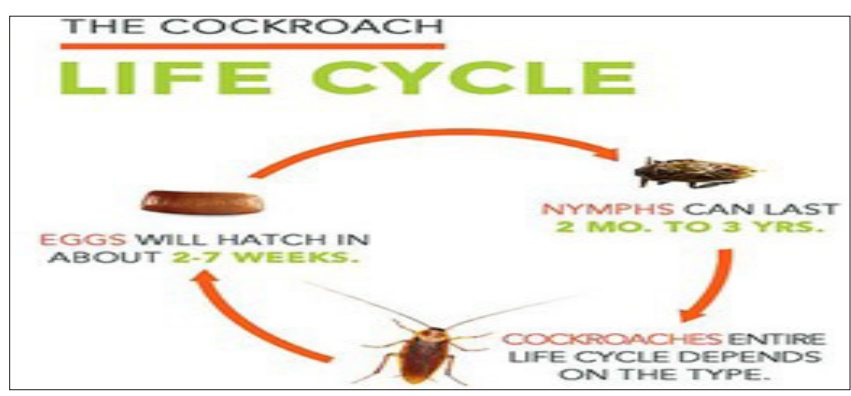

Figure 13.Life Cycle of Cockroach

\section{Management of Cockroaches}

\section{Sanitation Measures}

- Remove food and water sources using through cleaning procedures since Sanitation deprives cockroach's food, moisture and harbourage needed for their survival.

- Eliminate cockroach harbourages by caulking or similar structural repairs.

- Employ sticky barriers using rodent glue board adhesive or special insect trap adhesive to prevent cockroaches from climbing the legs of tables or other furniture.

- Maintain higher temperatures greater than $120^{\circ} \mathrm{F}$ for several hours, or cold at $0^{\circ} \mathrm{F}$ for 60 minutes (or several hours at $32^{\circ} \mathrm{F}$ ), where insecticides cannot be used or no residues are permitted.

- Keep counters, food preparation surfaces, kitchen appliances and floors as clean as possible.

- Periodically, intensively clean kitchen areas, in particular the floor, focusing on areas where grease accumulates, such as drains, vents, ovens and stoves. Put screens on vents, windows and ducts to reduce roach passage ways.

- Caulk around the edges of screens to make a tight barrier.

\section{Habitat Management}

- Keep food in tightly sealed, roach-resistant containers and leftover food inside a refrigerator.

- Store food waste and other organic materials in plastic containers with tight-fitting, snap-on lids.

- remove dead leaves or rake mulch away from the foundation.

- Check infested grocery bags when brought inside for cockroaches before storing.

- Keep grocery bags in outside storage areas.

- Check large openings around outside drainage lines and sewer vents and fix screens or sealed.

- Seal gaps between door frames and doors with weather stripping.

\section{Chemical Management}

Insecticide application/s should be complementary to above sanitation and habitat management measures but should not be exclusive (Table 2).
Table 2.Insecticides for cockroach management in India

\begin{tabular}{|c|c|}
\hline Active ingredient (a.i.) & Brand name \\
\hline $\begin{array}{c}\text { Imidacloprid } 21 \% \\
\text { Beta Cyfluthrin } 10.5 \%\end{array}$ & Temprid \\
\hline Alpha cypermethrin $10 \%$ SC & NT COCK \\
\hline Cyfluthrin 050 EW & SOLFAC \\
\hline Deltamethrin 2.5\% SC & K-Othrine \\
\hline Fipronil & Agenda \\
\hline Fipronil & Maxforce \\
\hline Imidacloprid & MAX FORCE Quantum \\
\hline
\end{tabular}

The insecticide application shall be made as crack and crevice, spot or general.

The following is the spray fluid can be prepared as below:

- Add water (1/2-1/3) volume of solution tank.

- Add pesticide according to label dilution rate.

- Replace pump assembly, tighten and shake vigorously for Uniform mixing open the assembly.

- Add water up to the desired level replace pump assembly, tighten and shake vigorously for uniform mixing.

The following is the spray procedure:

- Select appropriate spray nozzle.

- Pump until a tank pressure of 20 psi is reached. (approximately 10 times pumping).

- Spray smoothly until the point of runoff (20 inches from surface) Upon completion of work.

- Rinse solution tank with $1 / 2$ litre of water.

- Pump thrice sprays into an empty container.

- Repeat the procedure 3 times.

- Keep reinstate for use the next day.

\section{Post Spray Actions}

- Store solution tank empty and inverted, ready for next use.

- Use reinstate again in preparing a solution of the same chemical the next day.

Use ULV treatments for crack, crevices and void applications if legally registered. Use gel formulation in cracks and crevices to have long lasting efficacy.

\section{Monitoring}

- Confirm that previous treatment was effective.

- Check for new cockroach activity.

- Identify changes to the home or landscape to find vulnerability to cockroach invasion.

- Re inspect the treated premises as a follow up in two weeks' time. 
- Place cockroach monitors in identified strategic locations in treated premises this will help to provide pest sighting report to the authorities.

- The following are cockroach monitoring traps.

\section{Rodents}

Globally, infectious diseases pose the most important cause of death. Among known human pathogenic diseases, approximately $50 \%$ are zoonoses. When considering emerging infectious diseases separately $73 \%$ currently belong to the group of zoonoses.

Rodentia is a largest order of Mammals in the world comprising 2,277 species in 481 genera under 33 families. Major rodents found in India have been described in Table 3 (Figure 14). Rodents include squirrels, rats, mice, voles, gerbils, hamsters, dormice, porcupines etc. They are all mainly herbivores and their mode of feeding habits include gnawing, scraping or nibbling. They possess one pair of sharp, chisel-shaped incisors, in each of the upper and lower.

Rodents infest human dwellings, and their urine and faeces contaminate foodstuffs in enormous quantities. Rodents can also cause destruction aboard ships, crafts, rail cabins and motor lorries by gnawing through fittings, wiring, and circuitry, which can even cause short circuits resulting in fire hazard. Rats in particular occur in almost all human communities in both rural and urban areas. They have great propensity for dispersal. Rats can invade and establish in new lands easily. Many species of medical importance have been found and may pose serious danger to humans.

\section{Detection of Rodent Infestation}

The presence of rat in a given house can be detected by:

- Rat fecula (droppings): A fresh fecula is soft, moist and bright in colour while old fecula is dry, hard and fray to touch. Generally, the colour and size of rat fecula depends on what the rat has eaten and the type of rodent species respectively.

- $\quad$ Foot print and tail marks: For fresh fecula the foot print and tail mark is clean and greasy, whereas for old fecula it is old and dusty.

- Rat run ways: If a given area is infested by rats there exist a greasy marking on the pipe, beam, wire, floor, wall, rafter etc. Habitually rat follow the same run way between food, water, and harbourage.

- Distraction marks: Rat distract human properties like furniture, food, and clothing's due to their gnawing property.

Table 3.Field identification of the major rodents found in India

\begin{tabular}{|c|c|c|c|c|c|c|}
\hline Character & $\begin{array}{c}\text { Rattus } \\
\text { rattus } \\
\text { (Black rat) }\end{array}$ & $\begin{array}{c}\text { Rattus } \\
\text { norvegicus } \\
\text { (Brown Rat) }\end{array}$ & $\begin{array}{l}\text { Mus } \\
\text { musculus } \\
\text { (House } \\
\text { Mouse) }\end{array}$ & $\begin{array}{c}\text { Bandicota } \\
\text { indica (Greater } \\
\text { bandicoot Rat) }\end{array}$ & $\begin{array}{l}\text { Bandicota } \\
\text { bengalensis } \\
\text { (Indian } \\
\text { mole Rat) }\end{array}$ & $\begin{array}{c}\text { Suncus murinus } \\
\text { (Indian musk } \\
\text { Shrew) }\end{array}$ \\
\hline $\begin{array}{l}\text { Average } \\
\text { weight } \\
\text { (gms) }\end{array}$ & $8-12$ & 16 & 12 & 0.5 to 1000 & 350 & 23-147.3 \\
\hline Fur & Black & Brown & Grey & $\begin{array}{c}\text { Dark brown to } \\
\text { almost black in } \\
\text { colour }\end{array}$ & $\begin{array}{c}\text { dark brown or } \\
\text { brownish gray } \\
\text { body fur }\end{array}$ & $\begin{array}{l}\text { grey to almost } \\
\text { black }\end{array}$ \\
\hline Body & Slender & Heavy set & Small & Large & Large & Small \\
\hline $\begin{array}{c}\text { Muzzle } \\
\text { (mouth part, } \\
\text { nostril) }\end{array}$ & Pointed & Blunt & $\begin{array}{l}\text { Slender } \\
\text { (Sharp) }\end{array}$ & $\begin{array}{l}\text { Broad and } \\
\text { short }\end{array}$ & $\begin{array}{l}\text { Broad and } \\
\text { rounded }\end{array}$ & $\begin{array}{c}\text { Muzzle is narrow, } \\
\text { long and tapers } \\
\text { rostrally }\end{array}$ \\
\hline Tail & $\begin{array}{l}\text { Longer than } \\
\text { body + head }\end{array}$ & $\begin{array}{l}\text { Shorter than } \\
\text { body + head }\end{array}$ & $\begin{array}{c}\text { Equal to } \\
\text { body + head }\end{array}$ & $\begin{array}{l}\text { Tail is shorter } \\
\text { than its head } \\
\text { uniformly black } \\
\text { in colour }\end{array}$ & $\begin{array}{c}\text { Tark tail is } \\
\text { shorter than } \\
\text { the head-body } \\
\text { length }\end{array}$ & $\begin{array}{c}\text { Thick at the } \\
\text { base and a bit } \\
\text { narrower at the } \\
\text { tip }\end{array}$ \\
\hline Ears & $\begin{array}{l}\text { Large and } \\
\text { prominent }\end{array}$ & $\begin{array}{c}\text { Small } \\
\text { closely set }\end{array}$ & Very large & $30-40 \mathrm{~mm}$ & $\begin{array}{c}\text { pinkish in } \\
\text { shade, have } 18 \\
\text { mammae }\end{array}$ & $\begin{array}{l}\text { small external } \\
\text { ears }\end{array}$ \\
\hline Feeding & Omnivorous & Same & Same & omnivorous & omnivorous & Insectivorous \\
\hline
\end{tabular}




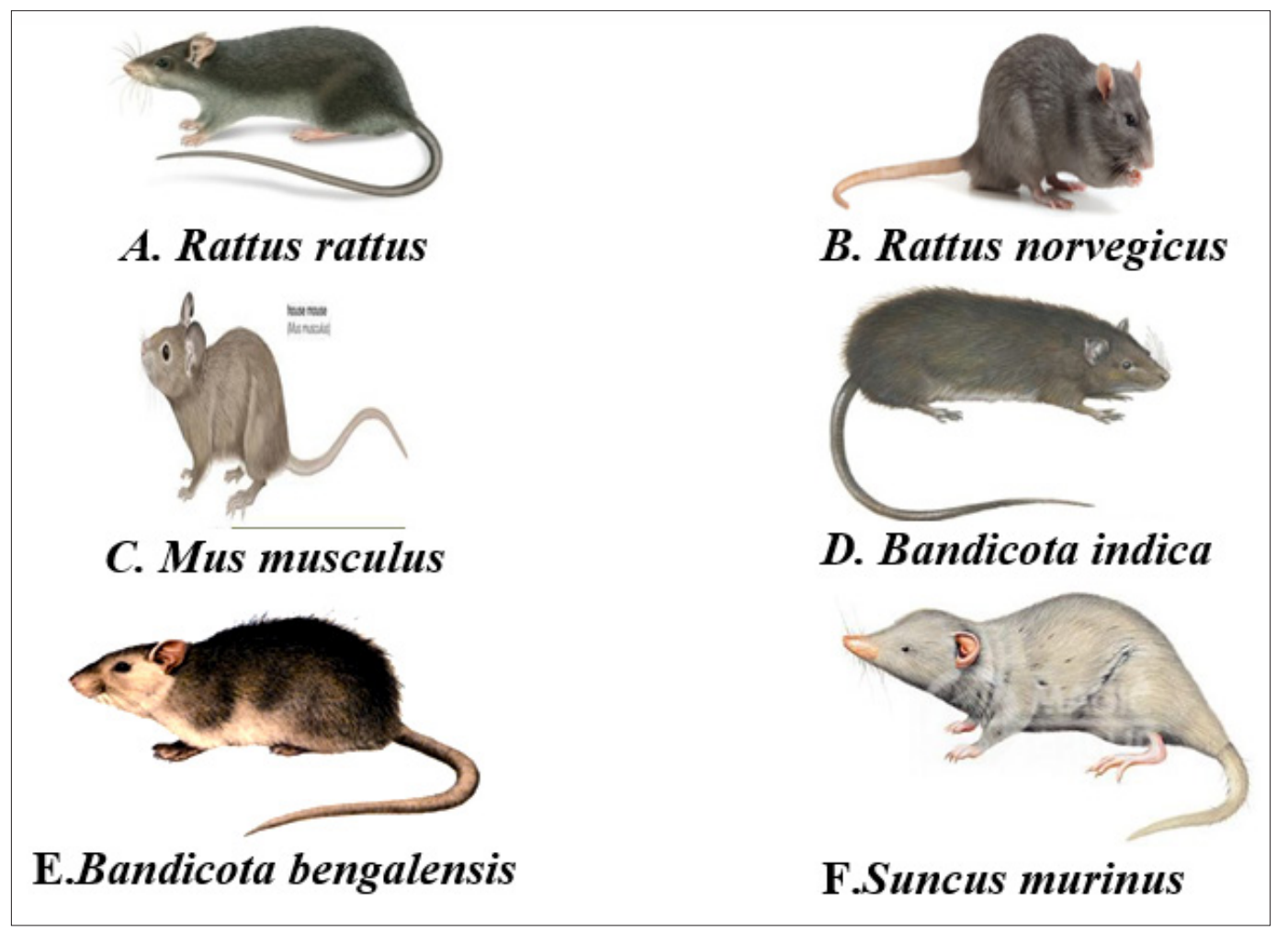

Figure 14. Major Rodents Found in India

\section{Rodent Surveillance}

Most rodent surveillance is accomplished to determine rodent presence and infestation levels in warehouses, dwellings and similar structures.

Surveillance programmes that monitor disease activity in susceptible rodent populations alert public health authorities to increased human plague risks, ${ }^{9}$ thus allowing prevention and control programmes to be implemented before human cases occur. Surveillance in this case is usually done by visual survey for faeces, damage, rub marks and sightings of dead or live rodents, or sometimes with live traps, snap traps or glue boards. Commensal rodents usually do not cause the problems in the field as they normally do at permanent installations, but other wild rodents may become nuisances or serve as reservoirs of disease. Rodents, as well as their ectoparasites, occasionally must be collected to determine the presence of known, or perhaps new, vector-reservoir systems (Annexure: V).

\section{Rodent Sampling Techniques}

The most common techniques for monitoring disease in rodent population include:

- Collecting and examining dead rodents.

- Monitoring activity among susceptible rodents.

- Trapping rodents for population data, serum, tissue samples and ectoparasite collections.

- Conducting serosurvey of carnivore populations that consume rodents.

\section{Trapping Rodents}

Systematically trapping and examining rodents is important to determine:

- The potential hosts in an area.

- The number and kinds of fleas infesting these rodents.

- Whether new rodent species have entered an area.

- Whether the abundance of resident rodent species has changed significantly since the previous trapping period.

Trapping is also a source of basic population ecology data, including:

1) Population densities (relative or absolute); 2) Age structures and reproductive status of rodent populations; 3) Rodent habitat preferences and 4) Local distribution.

Estimates of absolute densities of rodent populations (number of animals present per unit area) can be made using Percent trap success; a relative density estimate is more easily obtained. This quantity refers to the number of animals caught per unit effort and equals the number of rodents caught divided by the number of trapping periods, divided by the number of traps set per period, multiplied by 100 \{ (no. animals caught/no. trapping periods/no. trap sets per period) $\times 100=$ percent trap success.

The no. of rodents trapped is evaluated in terms of trap positivity rate which represents the average no. of small mammals captured per traps set and may be calculated by the formula given below: 


$$
\text { Trap positivity rate }=\frac{\text { No. of traps positive for rodents }}{\text { No. of traps laid }} \times 100
$$

$$
\begin{aligned}
& \text { Total No. of Flea Collected } \\
& \text { Flea Index: } \\
& - \text { Total No. of Rats Collected }
\end{aligned}
$$

\section{Rodent Prevention}

- Sanitation

- Rodent-guards

- Illumination for rodent movement restrictions

- Pier-side inspections/surveillance on-board ships

\section{Rodent Control}

- Conventional rat cage traps

- Spring board traps

- Glue traps

- Electronic rat-traps

- Sherman trap

\section{Micro-level Planning}

The steps that need attention on proper planning in unit areas are indicated below:

\section{Step I: Situation Analysis}

- Species of the area

- Position of infestation

- Condition of surrounding areas

- General lay out and situation of cropping season

- Decision on control

While making situation analysis the available resources, control technology and human attitudes are to be precisely judged.

\section{Step 2: Control Design}

- Type of control

- Hygiene

- Proofing

- Chemicals/natural products to be used

- Area to be controlled

- Time of control

- Staff requirement, people to be involved etc

\section{Step 3: Control Preparation}

- Make a plan of action

- Inform people involved for community participation

- Obtain equipment required

- Fix dates for various phases of control action

- Prepare rodenticide baits if necessary

\section{Step 4: Rodent Control}

- Carry out control activity

\section{Step 5: Monitoring}

- All planned actions need monitoring for amending, if need arises to conform to the original plan

- This situation may require an amending in the original plan

- Check signs of activity

- Note areas which require further action

- Decide on further action and type of action

- Continue monitoring

Step 6: Maintaining Low Rodent Population Density

- Complete management actions before on set of monsoons.

- They start breeding with onset of the monsoon and post monsoon months and rodent population reaches peak quickly and it becomes difficult to control them.

- Use acute poison like zinc phosphide, aluminium phosphide in case of serious rodent infestations only. Legal provisions need to be considered while planning aluminium phosphide fumigation.

- Use anticoagulants or other structural modification or environmental sanitation (for prevention) during low rodent density situations.

- Integrating these three measures, viz., application of chemical inputs with structural modifications and clean premises/ public places, can bring maximum reduction of rodent populations.

- Use bait stations wherever feasible considering their safety.

\section{Step 7: Timelines for Implementation of the Plan}

- Conduct monthly surveys in all urban habitations like parks, open areas, drains, canals, roads, garbage dumps, office complexes

- The periodicity can also be decided based on the local situations

- However, summer months are desirable since low rodent infestation would be there at that time

- Further, on monsoon entry, bacterial diseases can flare up, and hence summer months need to be targeted for rodent vector control

\section{Conflict of Interest: None}

\section{References}

1. WHO. Handbook for integrated vector management. Geneva 2014a.

2. WHO. A global brief on vector-borne diseases. World Health Organization, Geneva. 2014b.

3. WHO. International Health Regulations 2005. 2nd edition. WHO, Geneva. 2008.

4. Strickman D, Kittayapong P. Dengue and its vectors in Thailand: Calculated transmission risk from total pupal counts of Aedes aegypti and association of winglength measurements with aspects of larval habitat. 2003. The American Journal of Tropical Medicine and 
Hygiene 2003; 68(2): 209-217.

5. WHO. Equipment for vector control: specification guidelines. Geneva: World Health Organization. 2010.

6. WHO. Guidelines for testing the efficacy of insecticide products used in aircraft. Geneva. 2012.

7. WHO. Houseflies. In: Vector control: methods for use by individuals and communities. 1997.

8. WHO. Guidelines for testing the efficacy of insecticide products used in aircraft. Geneva. 2012.

9. WHO Regional Office for South-East Asia. Operational guidelines on plague surveillance, diagnosis, prevention and control. New Delhi: WHO Regional Office for SouthEast Asia. 2009b.

10. WHO. Vector Surveillance and Control at Ports, Airports, and Ground Crossings. 2016. 


\section{Annexures}

\section{Annexure: I}

\section{Mosquito Surveys}

\section{Adult Mosquito Collection Methods}

Equipment Sucking tube, Torchlight, paper cups with covering net, cotton, rubber bands, mosquito cages, a card box container or insulated picnic box, chloroform and towels.

Hand collection of indoor-resting mosquitoes.

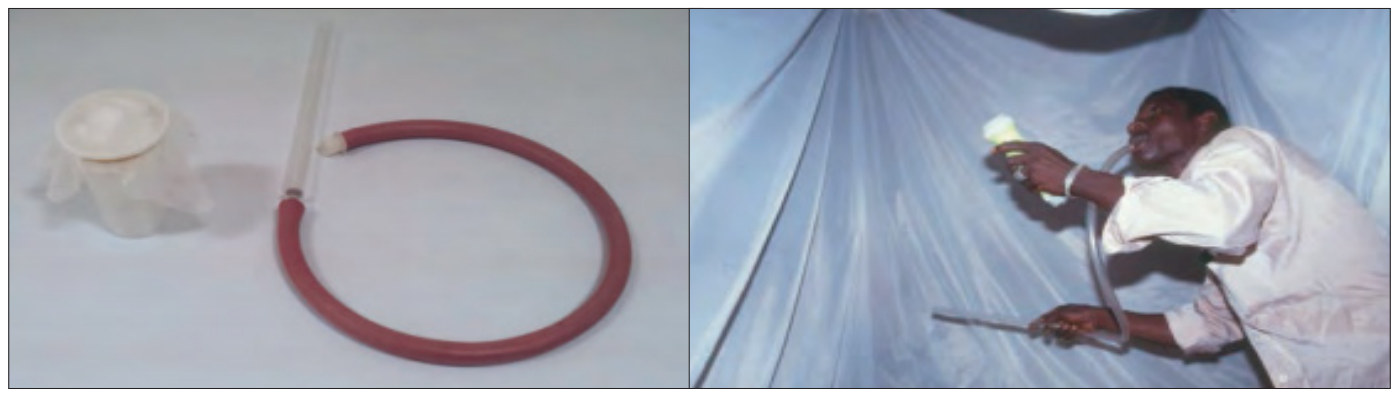

Figure I.Use of Aspirator Technique

Adult mosquitoes in indoor situations should be searched in dark corners of houses, ceilings, amongst thatch and cobwebs, on the underside of shelves, amongst clothing and other hanging articles with the help of torch light. Large number of mosquitoes may be collected from sheds used for cattle, horses and pigsties, etc.

\section{By Aspirator Tube or Sucking Tube}

This is the most widely used and convenient method for mosquito collection. Aspirator tube is generally having a length of 30-45 cms (internal diameter, 8-12 mm) and is made up of glass or plastic tubing. A piece of mosquito netting fixed over a short piece of smaller diameter rubber tuning, which is inserted into the end of larger tubing. A $50 \mathrm{~cm}$ long rubber tubing is slipped over the end of glass tubing provided with mosquito netting. The resting of feeding mosquito on being detected with torch light can be sucked in gently, unless to worker keeps sucking or closes the end of tube with a finger or cotton plug, the captured mosquitoes are liable to fly out.

\section{Larval Mosquito Collection}

To identify the preferred breeding sites, it is essential to be systematic and check all possible breeding places, even those that are difficult to reach. This will indicate the type of site most likely to harbour the larvae of anopheline mosquitoes.

\section{Objectives}

- To establish the breeding habits of different species.

- To establish the geographical distribution of the vectors.

- To establish the active breeding places.

- To study the development of aquatic stages.

- To evaluate the impact of anti-larval measures on the larval density.

- To collect samples of larvae for rearing adults for taxonomic studies or biological observation (bioassay/susceptibility tests).

\section{Equipment}

Dipper, larval net, large tray, pipette, specimen tubes (vials), 70\% alcohol solution, coon wool, a pencil, and safety match or lighter. If live specimens are required for insecticide testing, larger boles or a wide-mouthed vacuum ask will also be needed.

\section{Larval Collection Method}
1. Dipping
2. Netting
3. Pipetting. 


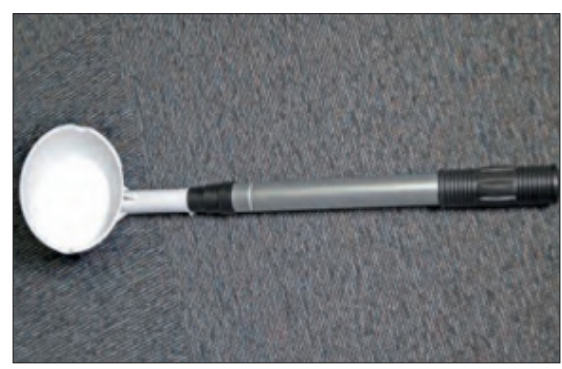

Figure 2.Laddle for dipping method

While dipping, care should be taken not to disturb the larvae and thus cause them to swim downwards - if they are disturbed, wait for a minute or two until they come up to the surface again and then continue dipping.

- Move along the breeding site, skimming the surface of the water with the dipper.

- Lift the dipper out of the water, making sure that the water containing the larvae and pupae is not spilled.

- Hold the dipper steady until larvae and pupae rise to the surface of the water.

- Collect the larvae and pupae by means of a pipette and transfer them to a bottle or vial.

\section{Dipping}

The dipping method is the most frequently used for the collection of mosquito larvae. The collecting equipment viz. Enamel bowl, flying pan or ladle (Figure $2 \& 3$ ) should be immersed in the breeding places (edges of swamps, ditches, streams, rice fields other bodies of waters) at an angle of 450.

The surface water will flow into the larval container automatically along with the larvae, if any. If the dipper is immersed too slowly the larvae are disturbed and go to the bottom. There should be an interval of 2-3 minutes between each dip to allow stage III IV larvae and pupae to come to the surface again.

In case surface should be agitated to cause the larvae to sink, clear away the vegetation and then wait for 3-4 minutes for larva to come to the surface and collect them with dipper. The larval density is assessed in terms of average larval density per dip.

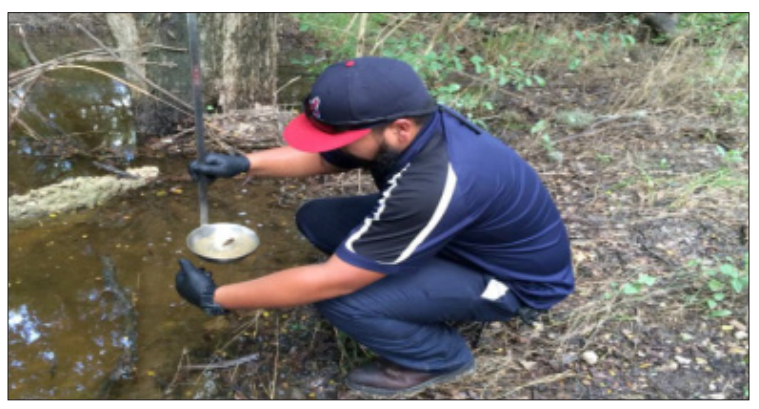

Figure 3.Use of Ladle in Dipping method

\section{Netting}

Larvae may be collection from large stretches of water along the edge of streams, ponds, wells, and other large water bodies.

A larval net (Figure 9) consists of a ring of iron frame, so-25 cm in diameter, to which a nylon/ muslin cloth net is attached, measuring about $10 \mathrm{~cm}$ long. A long wooden handle is attached to the ring. For collecting larvae, the net is held at an angle of 300 and skimmed rapidly through the surface water near emerging or floating vegetation. The net is inverted and washed out in a bowl of water and the larvae collected with a pipette.

The density is measured in terms of density per larval net. The usual pond net devoid of handle and provided with nylon string attached to four points on the iron ring at equal distances is used for collecting larvae from wells. Join the four pieces of string are such a way that the ring forms an angle of 300 and attach this to a rope tied with it. While collecting larvae from a well, put a small weight in the net to keep its bottom under the water surface. The net is moved around the border of the well two three times, it is then withdrawn, inverted in a white enamel bowl containing water. The larvae are collected by pipette. The density is measured in terms of larvae per well net. 


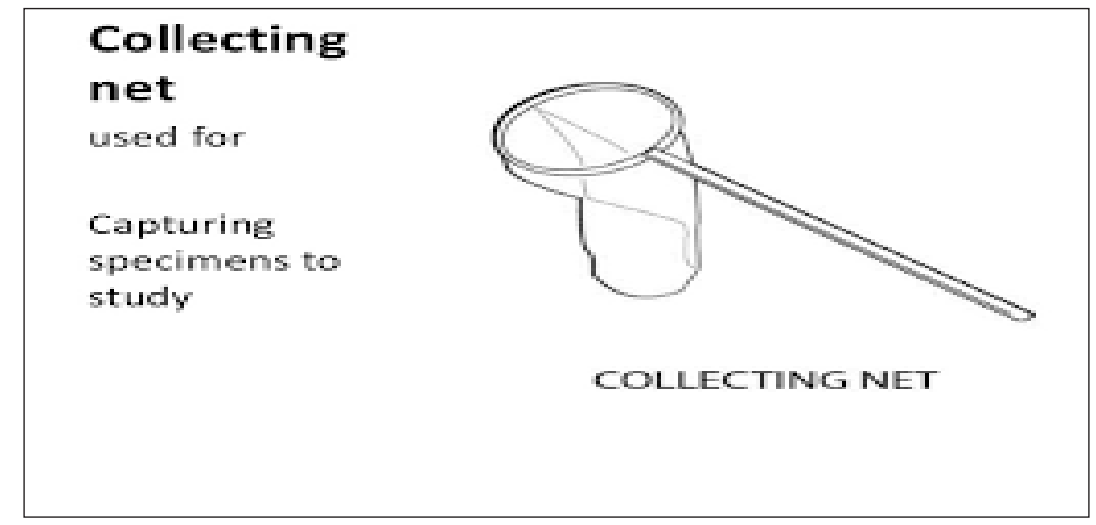

Figure 4.Netting method

\section{Pipetting}

Small pipettes or small spoons may be used for collecting larvae from the shallow breeding sites like hoof prints, etc.

Larval surveillance is vital for predicting adult emergence and establishing optimal frequency of application of larval control measures. Larval surveillance is also helpful in forecasting the need for adult mosquito control, as well as to assess the effectiveness of control measures. Various indices are used to express results of larval monitoring. The most popular indices are the Breeding Index, House Index, Container Index, Breteau Index, and Pupal Index.

- House Index (HI): Number of houses positive for Aedes x 100 / Number of houses inspected.

- Container index (CI): Number of positive containers for Aedes $x 100$ / Number of containers inspected.

- Breteau index (BI): Number of positive containers for Aedes x 100 / Number of houses inspected. 


\section{Annexure: II}

\section{Procedure for Vector Surveillance}

The following is the step-by-step approach of larval surveys and identification of mosquitoes at the harbour area of ports and at airport platforms, hangers, baggage, cargo areas, and at ground crossings.

- Detect and map all potential breeding sites of vectors at the point of entry and surrounding 400-metre perimeter where human habitation occurs or the port is established.

- Take photographs of the breeding sites.

- Make an inventory of potential breeding sites of vectors/ mosquitoes and update it seasonally and temporally. Categorize them into temporary and permanent breeding sites.

- Organize larval surveys using appropriate sampling methods.

- Collect larvae (also pupae if found in the same habitat) in screw-cap plastic containers along with water from the larval habitat and bring samples to the insectary for rearing and emergence. Fill the container 3/4 with water and secure the cap tightly. Label each container, mentioning breeding site, its specific location, and date of collection of samples. Note that during transportation of sample in a vehicle, jerks must be avoided as these can result in mechanical injury and mortality in larvae.

- Gently pour out water along with immature stages of mosquitoes into a $300 \mathrm{ml}$ bowl or basin or a plastic/enamel tray.

- Mix finely ground powdered yeast and ground dog biscuits in a proportion of 60:40 as larval feed daily. Baby formula food along with fish meal flakes ground to powder and mixed in equal proportion may also be used.

- Cover the bowl with muslin cloth secured outside on the brim of the bowl with a rubber band.

- Segregate pupae from larvae and keep them separately in similarly secured bowls and wait till the emergence of adults.

- Remove adults carefully from the bowl by inserting the plastic tube of a hand-held standard mouth aspirator through the hole in the netting or use a motorized aspirator. As far as possible use a mouth aspirator, which will avoid injury to adults that may occur when using a motorized aspirator. Transfer the adults gently into a test tube and close the tube using a cotton plug to prevent mosquitoes from escaping.

- Anaesthetize the adults using a few drops of ether and wait till the mosquitos are knocked down and their movements stop completely.

- Identify knocked-down adults under a dissecting binocular microscope using standard morphological keys, transfer them to a designated referral laboratory, or retain the specimen for PCR-based molecular identification if local capability exists.

\section{Material Required for Adult Catches of Mosquitoes}

The following is needed to catch adult mosquitoes:

- Field bag of a sufficiently large size

- Hand held and/or motorized aspirator and adult traps (light traps with or without carbon dioxide, CDC, UV, or BGSentinel traps)

- Test tubes

- Paper sticker labels for labelling test tubes containing adult collection

- Cotton roll

- Torch and batteries

- Forceps (one blunt and one sharp)

- White cloth sheets for space spray

- Knockdown atomized insecticide can

- Field notebook and pen

- Soap

- Small towel

- Protective gear: The frequency of adult collection should be at least monthly in vulnerable areas or more frequently (weekly/fortnightly) in areas with weather conditions that allow for a greater probability of vector survival and establishment.

\section{Vector Control}

Integrated vector management Integrated Vector Management (IVM) is defined as «a rational decision-making process for the optimal use of resources for vector control» and includes five key elements: 1) evidence-based decision-making; 2 ) integrated approaches 3); collaboration within the health sector. 


\section{Annexure: III}

\section{Proforma for Dengue Surveillance}

\begin{tabular}{|c|c|c|c|c|c|c|c|c|c|c|c|c|c|c|c|c|c|c|c|}
\hline \multirow{2}{*}{$\begin{array}{l}\dot{0} \\
\dot{n}\end{array}$} & \multirow{2}{*}{ 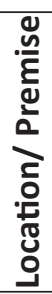 } & \multicolumn{2}{|c|}{$\frac{\grave{d}}{\text { ¿ }}$} & \multicolumn{2}{|c|}{ 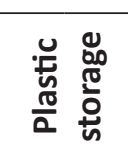 } & \multicolumn{2}{|c|}{ 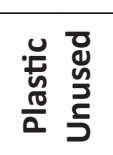 } & \multicolumn{2}{|c|}{ 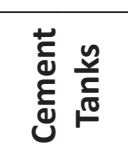 } & \multicolumn{2}{|c|}{ 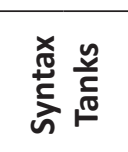 } & \multicolumn{2}{|c|}{ 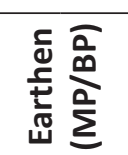 } & \multicolumn{2}{|c|}{ 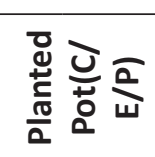 } & \multicolumn{2}{|c|}{ 흐 $\frac{0}{4}$} & \multicolumn{2}{|c|}{$\frac{n}{\frac{n}{2}}$} \\
\hline & & 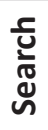 & $\underset{+}{\$}$ & 岳 & $\sum_{+}^{\Perp}$ & $\begin{array}{l}\frac{5}{0} \\
\frac{1}{0} \\
\text { ஸे }\end{array}$ & $\stackrel{\$}{\beth}$ & $\begin{array}{l}\frac{1}{0} \\
\frac{1}{\pi} \\
\text { ஸे }\end{array}$ & 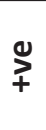 & $\begin{array}{l}\frac{1}{0} \\
\frac{1}{0} \\
\text { ปั }\end{array}$ & 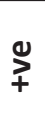 & $\begin{array}{l}\frac{c}{0} \\
\frac{0}{\pi} \\
\text { ปั }\end{array}$ & 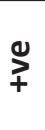 & $\begin{array}{l}\frac{1}{0} \\
\frac{1}{0} \\
\stackrel{4}{10}\end{array}$ & 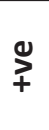 & 岳 & $\stackrel{\square}{\$}$ & 它 & $\underset{+}{\searrow}$ \\
\hline & & & & & & & & & & & & & & & & & & & \\
\hline & & & & & & & & & & & & & & & & & & & \\
\hline & & & & & & & & & & & & & & & & & & & \\
\hline & & & & & & & & & & & & & & & & & & & \\
\hline & & & & & & & & & & & & & & & & & & & \\
\hline & & & & & & & & & & & & & & & & & & & \\
\hline & & & & & & & & & & & & & & & & & & & \\
\hline & & & & & & & & & & & & & & & & & & & \\
\hline & & & & & & & & & & & & & & & & & & & \\
\hline & & & & & & & & & & & & & & & & & & & \\
\hline & & & & & & & & & & & & & & & & & & & \\
\hline & & & & & & & & & & & & & & & & & & & \\
\hline
\end{tabular}

MP-Mud Pot, BP- Bird Pot; C-Cement pot, E- Earthen pot, P- Plastic pot; Solid waste* includes tyres, unused cup, broken glasses

No. of Premises Checked $(A)=$ No. of Premises Positive $(B)=$ Premises Index $=[B \times 100 / A]=$

No. of Containers Checked $(C)=$ No. of Containers Positive $(D)=$ Container Index $=[D \times 100 / C]=$

$B I=[D \times 100 / A]=$ No. of Pupae $(P)=$ Pupal Index $=[P / A \times 100]=$ 


\section{Annexure: IV}

\section{Laboratory Requirements for the Vector Surveillance and Control}

\section{Laboratory}

1. Adequate lighting

2. Air conditioning

3. Air curtains

4. Working desk

5. Paper/ cork pin-up board

6. Comfortable revolving chair/stool

7. Iron racks for adult mosquito cages or desks

8. Storage cabinets

9. Insect cabinet

\section{Equipment}

1. Binocular dissecting microscope with spare parts (especially bulbs when equipped with internal light source)

2. Binocular compound microscope with spare parts (especially bulbs when equipped with internal light source)

3. Hand lens

4. Refrigerator

5. Rat traps (spring board, conventional iron cage, glue trap)

III. Chemicals and reagents

1. Immersion oil

2. Distyrene-Plasticiser-Xylene (DPX), mountant

3. Para-dichlorobenzene

4. $\mathrm{NaCl}$

5. Giemsa stain (ready to use)

IV. Glassware, plasticware, and minor instruments and materials

1. Petri plates

2. Glass slides

3. Cover slips

4. Test tubes

5. Watch glasses

6. Tweezers

7. Dissecting needles

8. Cotton-wool

1. 10 Gloves

10. Plastic bowls (capacity $300 \mathrm{~mL}$ )

11. Net cloth

12. Rubber bands

13. Mosquito cage stands 


\section{Annexure: V}

Details of the Rodent samples collected

Date: Place/village:

SM - Suncusmurinus, RR - Rattus rattus, MM - Mus musculus, MO-Mole

Table I.Performa used for Rodent Survey

\begin{tabular}{|c|c|c|c|c|c|c|c|c|c|c|c|c|}
\hline \multirow[t]{2}{*}{$\begin{array}{l}\text { S. } \\
\text { No. }\end{array}$} & \multirow{2}{*}{$\begin{array}{l}\text { Cage } \\
\text { Code/ } \\
\text { Place }\end{array}$} & \multirow{2}{*}{$\begin{array}{c}\text { Rodent } \\
\text { Species } \\
\text { (Male/ } \\
\text { Female) }\end{array}$} & \multicolumn{3}{|c|}{ Ecto-parasites } & \multirow{2}{*}{$\begin{array}{c}\text { Ear Pinna } \\
\text { Collected } \\
(70 \% \\
\text { alcohol) }\end{array}$} & \multirow{2}{*}{$\begin{array}{l}\text { Blood/ } \\
\text { Serum } \\
\text { sample }\end{array}$} & \multirow[t]{2}{*}{ Smear } & \multicolumn{4}{|c|}{ Organs Collected in Media } \\
\hline & & & Mite & Tick & Flea & & & & Heart & Lung & Liver & Spleen \\
\hline & & & & & & & & & & & & \\
\hline & & & & & & & & & & & & \\
\hline & & & & & & & & & & & & \\
\hline & & & & & & & & & & & & \\
\hline & & & & & & & & & & & & \\
\hline & & & & & & & & & & & & \\
\hline & & & & & & & & & & & & \\
\hline & & & & & & & & & & & & \\
\hline & & & & & & & & & & & & \\
\hline & & & & & & & & & & & & \\
\hline & & & & & & & & & & & & \\
\hline
\end{tabular}




\section{Annexure: VI}

Table I. Larvicides Formulations and Dosages as approved by NVBDCP

\begin{tabular}{|c|c|c|c|c|c|c|c|c|c|}
\hline ì & 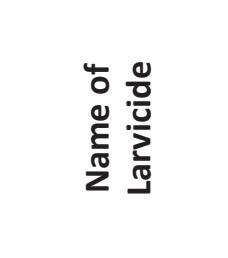 & 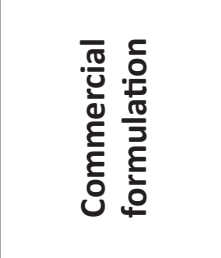 & 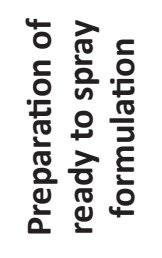 & 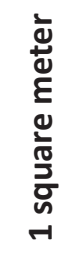 & 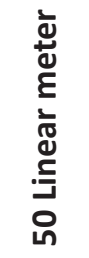 & 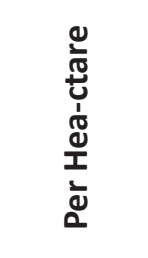 & 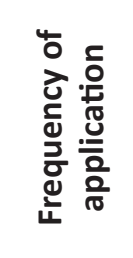 & 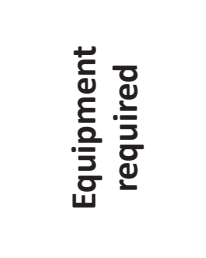 & 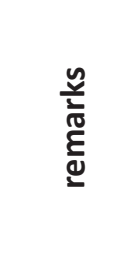 \\
\hline 1. & MLO & $\begin{array}{c}100 \% \\
\text { petroleum } \\
\text { project } \\
\text { product }\end{array}$ & As it is & $\begin{array}{l}20 \\
\text { C.C. }\end{array}$ & $\begin{array}{c}1 \\
\text { Litre }\end{array}$ & $\begin{array}{l}200 \\
\text { Litres }\end{array}$ & Weekly & $\begin{array}{l}\text { Knapsack/ } \\
\text { hand } \\
\text { compression } \\
\text { sprayer }\end{array}$ & $\begin{array}{l}\text { To be } \\
\text { applied } \\
\text { along } \\
\text { the } \\
\text { shore of } \\
\text { water } \\
\text { body }\end{array}$ \\
\hline 2. & $\begin{array}{l}\text { Temephos } \\
\text { (Abate) }\end{array}$ & $50 \% \mathrm{EC}$ & $\begin{array}{c}2.5 \text { c.c. } \\
\text { in } 10 \\
\text { litres of } \\
\text { potable } \\
\text { water }\end{array}$ & $\begin{array}{l}20 \\
\text { C.C. }\end{array}$ & $\begin{array}{c}1 \\
\text { Litre }\end{array}$ & $\begin{array}{l}200 \\
\text { Litres }\end{array}$ & -do- & $\begin{array}{l}\text { Knapsack/ } \\
\text { hand } \\
\text { compression } \\
\text { sprayer }\end{array}$ & $\begin{array}{c}\text { Can be } \\
\text { applied } \\
\text { in clean } \\
\text { water }\end{array}$ \\
\hline 3. & $\begin{array}{c}\text { Bacillus } \\
\text { thurin- } \\
\text { giensisvar } \\
\text { israelensis } \\
164 \mathrm{H} \\
\text { Wettable } \\
\text { Powder (WP) }\end{array}$ & & $\begin{array}{c}5 \mathrm{~kg} \text { in } \\
200 \text { litres } \\
\text { of water }\end{array}$ & - & - & $5 \mathrm{~kg}$ & $\begin{array}{l}\text { Fort- } \\
\text { nightly }\end{array}$ & $\begin{array}{l}\text { Knapsack/ } \\
\text { hand } \\
\text { compression } \\
\text { sprayer }\end{array}$ & $\begin{array}{l}\text { For both } \\
\text { clean } \\
\text { and } \\
\text { non- } \\
\text { potable } \\
\text { polluted } \\
\text { water }\end{array}$ \\
\hline \multirow{2}{*}{4.} & \multirow{2}{*}{$\begin{array}{l}\text { Bacillus } \\
\text { thurin- } \\
\text { giensisvar } \\
\text { israelensis } \\
12 \text { Aqueous } \\
\text { Suspension } \\
\quad \text { (AS) }\end{array}$} & \multirow{2}{*}{$\begin{array}{l}\text { Aqueous } \\
\text { suspension } \\
12 \text { Aqueous } \\
\text { Suspension }\end{array}$} & $\begin{array}{l}1 \text { litre in } \\
200 \text { litres } \\
\text { of water }\end{array}$ & - & - & 1 Lit. & Weekly & $\begin{array}{l}\text { Knapsack/ } \\
\text { hand } \\
\text { compression } \\
\text { sprayer }\end{array}$ & $\begin{array}{l}\text { Clean } \\
\text { water }\end{array}$ \\
\hline & & & $\begin{array}{c}2 \text { litres } \\
\text { in } 200 \\
\text { litres of } \\
\text { water }\end{array}$ & - & - & 2 Lit. & Weekly & $\begin{array}{l}\text { Knapsack/ } \\
\text { hand } \\
\text { compression } \\
\text { sprayer }\end{array}$ & $\begin{array}{l}\text { Polluted } \\
\text { water }\end{array}$ \\
\hline 5. & $\begin{array}{c}\text { Diflubenzuron } \\
25 \%\end{array}$ & $\begin{array}{l}25 \% \text { wettable } \\
\text { powder }\end{array}$ & $\begin{array}{c}100 \mathrm{gm} \\
\text { in } 100 \\
\text { litre of } \\
\text { clean } \\
\text { water } \\
200 \mathrm{gm} \\
\text { in } 100 \\
\text { litre of } \\
\text { polluted } \\
\text { water }\end{array}$ & - & - & $\begin{array}{c}25 \mathrm{gm} \\
\text { a.i. } \\
50 \mathrm{gm} \\
\text { a.i. }\end{array}$ & Weekly & $\begin{array}{l}\text { Knapsack/ } \\
\text { hand } \\
\text { compression } \\
\text { sprayer }\end{array}$ & $\begin{array}{c}\text { Clean } \\
\text { water } \\
\text { Polluted } \\
\text { water }\end{array}$ \\
\hline 6. & Pyriproxyfen & $0.5 \%$ granular & $\begin{array}{l}\text { Ready to } \\
\text { use }\end{array}$ & - & - & $\begin{array}{c}2 \mathrm{~kg} \\
\text { Clean } \\
\text { water } \\
4 \mathrm{~kg} \\
\text { Polluted } \\
\text { water }\end{array}$ & Weekly & $\begin{array}{l}\text { Granular } \\
\text { applicator } \\
\text { / Hand } \\
\text { broadcast }\end{array}$ & $\begin{array}{c}\text { Clean } \\
\text { water } \\
\text { Polluted } \\
\text { water }\end{array}$ \\
\hline
\end{tabular}


Table 2. Insecticides Formulation and its Dosages

\begin{tabular}{|c|c|c|c|c|c|c|}
\hline $\begin{array}{c}\text { S. } \\
\text { No. }\end{array}$ & $\begin{array}{c}\text { Name of } \\
\text { Insecticide }\end{array}$ & $\begin{array}{c}\text { Amount of } \\
\text { insecticide to } \\
\text { prepare 10 liters } \\
\text { of suspension }\end{array}$ & $\begin{array}{c}\text { Dosage per } \\
\text { sq. meter of } \\
\text { active } \\
\text { ingredient }\end{array}$ & $\begin{array}{c}\text { Residual } \\
\text { effect } \\
\text { in weeks }\end{array}$ & $\begin{array}{c}\text { Area (in sq. m) } \\
\text { to be covered } \\
\text { by 10 liters of } \\
\text { suspension }\end{array}$ & $\begin{array}{c}\text { Requirement } \\
\text { of insecticide per } \\
\text { million population } \\
\text { (in MT) }\end{array}$ \\
\hline 1. & DDT 50\% WP & $1.000 \mathrm{~kg}$ & $1 \mathrm{gm}$ & $10-12$ & 500 & 150.00 \\
\hline 2. & Malathion 25\% WP & $2.000 \mathrm{~kg}$ & $2 \mathrm{gm}$ & $6-8$ & 500 & 900.00 \\
\hline 3. & Deltamethrin 2.5 WP & $0.400 \mathrm{~kg}$ & $20 \mathrm{mg}$ & $10-12$ & 500 & 60.00 \\
\hline 4. & Cyfluthrin 10\% WP & $0.125 \mathrm{~kg}$ & $25 \mathrm{mg}$ & $10-12$ & 500 & 18.75 \\
\hline 5. & $\begin{array}{c}\text { Lambda cyhalothrin } \\
10 \% \text { WP }\end{array}$ & $0.125 \mathrm{~kg}$ & $25 \mathrm{mg}$ & $10-12$ & 500 & 18.75 \\
\hline 6. & $\begin{array}{c}\text { Alphacypermethrin } \\
5 \% \text { WP }\end{array}$ & $0.250 \mathrm{~kg}$ & $25 \mathrm{mg}$ & $10-12$ & 500 & 37.50 \\
\hline 7. & Bifenthrin 10\% WP & $0.125 \mathrm{~kg}$ & $25 \mathrm{mg}$ & $10-12$ & 500 & 18.75 \\
\hline
\end{tabular}

Table 3.Adulticides for Indoor Space Spray

\begin{tabular}{|c|c|c|c|c|c|}
\hline $\begin{array}{c}\text { S. } \\
\text { No. }\end{array}$ & $\begin{array}{c}\text { Name of } \\
\text { insecticide }\end{array}$ & $\begin{array}{c}\text { Commercial } \\
\text { formulation }\end{array}$ & Preparation of Formulation & $\begin{array}{c}\text { Equipment } \\
\text { required }\end{array}$ & Remarks \\
\hline 1. & Pyrethrum extract & $2.0 \%$ extract & $\begin{array}{c}1: 19 \text { i.e. } 1 \text { part of } 2 \% \text { Pyrethrum } \\
\text { extract in } 19 \text { part of Kerosene } \\
(50 \mathrm{ml} \text { in } 1 \text { litre } \mathrm{K} . \text { oil) }\end{array}$ & $\begin{array}{c}\text { Pressurized } \\
\text { spray machine } \\
\text { or fogging } \\
\text { machine }\end{array}$ & $\begin{array}{c}\text { Used for } \\
\text { indoor spray }\end{array}$ \\
\hline 2. & Cyphenotherin & $5 \% \mathrm{EC}$ & $\begin{array}{c}0.5 \mathrm{gm} \text { a.i. Per sq meter }(20 \mathrm{ml} \mathrm{in} \\
1 \text { litre of K. oil) }\end{array}$ & - \\
\hline
\end{tabular}




\section{Annexure-VII}

Table I.List of International Airports

\begin{tabular}{|c|c|c|}
\hline Andhra Pradesh & Hyderabad & Rajiv Gandhi International Airport \\
\hline Assam & Guwahati & Lokpriya Gopinath Bordoloi International Airport \\
\hline Delhi & New Delhi. & Indira Gandhi International Airport \\
\hline Gujrat & Ahmedabad & Sardar Vallabhbhai Patel International Airport \\
\hline Karnataka & Bengaluru & Kempegowda International Airport \\
\hline Jammu \& Kashmir & Srinagar & Srinagar International Airport \\
\hline Punjab & Amritsar & Sri Guru Ram Dass Jee International Airport \\
\hline Rajasthan & Jaipur & Jaipur International Airport \\
\hline Uttar Pradesh & Lucknow & Chaudhary Charan Singh International Airport \\
\hline Uttar Pradesh & Varanasi & Lal Bahadur Shastri International Airport. \\
\hline West Bengal & Kolkata & Netaji Subha Chandra Bose International Airport \\
\hline Maharashtra & Nagpur & Dr. Babasaheb Ambedkar International Airport \\
\hline Maharashtra & Mumbai & Chhatrapati Shivaji International Airport \\
\hline Goa & Vasco-da-Gama (Dabolim) & Goa International Airport \\
\hline Tamil Nadu & Chennai & Chennai International Airport \\
\hline Kerala & Calicut & Calicut International Airport \\
\hline Tamil Nadu & Coimbatore & Coimbatore International Airport \\
\hline Tamil Nadu & Tiruchirappalli & Tiruchirappalli International Airport \\
\hline Kerala & Kochi & Cochin International Airport \\
\hline Kerala & Thiruvananthapuram & Trivandrum International Airport \\
\hline Andaman \& Nicobar Islands & Port Blair & Veer Savarkar International Airport \\
\hline
\end{tabular}

Table 2.List of International Seaports

\begin{tabular}{|l|l|l|}
\hline West Bengal & Kolkata & Kolkata Port Trust \\
\hline West Bengal & Haldia, Midnapore & Haldia Dock Complex \\
\hline Orissa & Jagatsingpur & Paradip Port Trust \\
\hline Andhra Pradesh & Visakhapatnam & Visakhapatnam Port Trust \\
\hline Tamil Nadu & Chennai & Chennai Port Trust \\
\hline Kerala & Willingdon Island, Cochin & Cochin Port Trust \\
\hline Karnataka & Mangalore & New Mangalore Port Trust \\
\hline Goa & Mormugoa & Mormugoa Port Trust \\
\hline Maharashtra & Mumbai & Mumbai Port Trust. \\
\hline Maharashtra & Mumbai & Jawaharlal Nehru Port Trust \\
\hline Gujrat & Kutch & Kandla Port Trust \\
\hline Tamil Nadu & Chennai & Ennore Port Limited \\
\hline
\end{tabular}

